\title{
Exploring the Potential of Alternative Pozzolona Cement for the Northern Savannah Ecological Zone in Ghana
}

\author{
Abdul-Manan Dauda \\ Tamale Polytechnic, Department of Building Technology, Tamale, Ghana \\ Email address: \\ ddabdul-manan@tamalepoly.edu.gh \\ To cite this article: \\ Abdul-Manan Dauda. Exploring the Potential of Alternative Pozzolona Cement for the Northern Savannah Ecological Zone in Ghana. \\ American Journal of Civil Engineering. Vol. 4, No. 3, 2016, pp. 74-79. doi: 10.11648/j.ajce.20160403.12
}

Received: March 25, 2016; Accepted: April 5, 2016; Published: April 26, 2016

\begin{abstract}
This project evaluates the performance of pozzolana cement elements produced from alternative raw materials with a view using them in low-cost housing. It also seeks the reduction of waste from agricultural sources and the cost of sandcrete blocks by using locally available materials. The need to find alternative materials to replace existing conventional ones has necessitated research into substitutes to cement with a view to investigating their usefulness to wholly or partly substitute ordinary Portland cement in the production of sandcrete blocks. This project investigates the possible use of Corn Cob Ash (CCA) as a partial replacement of cement in sandcrete block production. 140 no. $450 \mathrm{mmx} 150 \mathrm{~mm} \times 225 \mathrm{~mm}$ solid sandcrete blocks of mix ratio 1:8 were cast, cured and crushed at 7,14,21, and 28 days. The corn cob ash was replaced at 0 to 40 percent levels at $5 \%$ intervals. The maximum compressive strength of $2.10 \mathrm{~N} / \mathrm{mm} 2$ was recorded at $30 \%$ replacement on the 28th day. After 12 months of exposure under northern savannah climatic conditions, the compressive strength remained stable or even increased with the weathering exposure. The maximum value of $2.10 \mathrm{~N} / \mathrm{mm} 2$ for the $30 \%$ replacement level is found suitable and recommended for building construction having attained a 28 -day compressive strength of more than $2.0 \mathrm{~N} / \mathrm{mm} 2$ as required by the National Building Code for non load bearing walls.
\end{abstract}

Keywords: Pozzolana-Cement, Construction Materials, Low-Cost Housing, Sandcrete, Corn Cob Ash, Northern Savannah, Ghana

\section{Introduction}

The importance of sandcrete blocks as part of local building materials cannot be over emphasized in building and construction industry in Ghana. Sandcrete blocks have been widely used for building construction in the country in general and are increasingly replacing mud and stabilized earth as a walling material in the savannah ecological zone. The rapid adoption of these blocks has encouraged investigations into ways to make it more efficient and affordable. It is also an observable fact that river sand which is an important ingredient in making sandcrete blocks is widely available in the study area as a result of the many rivers and water bodies that traverse it.

Maize is the most important cereal crop produced in Ghana and it is also the most widely consumed staple food in Ghana with increasing production since 1965 (FAO, 2008; Morris et al., 1999). In Ghana, maize is produced predominantly by smallholder resource poor farmers under rain-fed conditions (SARI, 1996). With these quantities comes the accompanying waste from corn husk and cob.

The cost of cement is a major issue for many builders in the study area. Therefore exploring the possible use of a commonly occurring waste material as a cement substitute will constitute an equally major relief for builders.

\section{Theoretical Framework}

Sandcrete blocks are composite material made up of cement, sand and water, moulded into different sizes. It is widely used in Ghana as a walling unit. The quality of blocks produced however, differs from due to the different methods employed in the production and the properties of the constituent materials.

Cement is a material with cohesive and adhesive properties when mixed with water, which makes it capable of bonding material fragments into a compact whole (Neville, 1996). Cements are classified as calcium silicate 
and calcium aluminate cement. Calcium silicate cement is further classified into Portland and Slag, while calcium aluminate is classified into High alumina and Pozzolona cement (Jackson and Dhir, 1991). Corn husk and cob has recently been recognized as pozzolona. A pozzolona is a siliceous/ aluminous material which in itself has little or no cementious value, but which will in finely divided form and in the presence of moisture, chemically reacts with calcium hydroxide liberated during the hydration of Portland cement to produce stable, insoluble cementious compound which contributes to its strength and impermeability (Sima, 1974).

Corn husk and cob ash is one of the promising pozzolanic materials that can be blended with Portland cement for the production of durable concrete/ blocks and at the same time it is a value added product. Addition of corn husk/cob ash to Portland cement does not only improve the early strength of concrete/block, but also forms a calcium silicate hydrate $(\mathrm{CSH})$ gel around the cement particles which is highly dense and less porous, and may increase the strength of concrete/block against cracking (Saraswathy and Ha- Won, 2007).

Many countries including Ghana have the problem of shortage of conventional cementing materials. Recently there are considerable efforts worldwide of utilizing indigenous and waste, materials in concrete. One of such materials is the corn husk/cob which under controlled burning, and if sufficiently ground, the ash that is produced can be used as a cement replacement material in concrete (Anwar et al, 2000). Corn husks/cobs are used as building materials; lightweight concrete briquettes have been made from partly burnt husks/cobs. Insulating blocks have also been made with cement and husk ash that resists very high temperatures (Grith, 1974).

Corn cob is the hard thick cylindrical central core of maize (on which are borne the grains or kernels of an ear of corn). Raheem (2010) described Corn cob as the agricultural waste product obtained from maize or corn; which is the most important cereal crop in sub-Saharan Africa. There had been various research efforts on the use of corn cob ash (CCA) and other pozzolana as a replacement for cement in concrete. Olutoge et al(2010); presented a comparative study on fly ash and ground granulated blast furnace slag (GGBS) high performance concrete, Ogunfolami (1995); considered mixing of the CCA with Ordinary Portland cement at the point of need (i.e. on site). Adesanya and Raheem (2010); studied the workability and compressive strength characteristics of Corn cob ash (CCA) blended cement concrete. Adesanya and Raheem (2009); also assessed the development of Corn cob ash (CCA) Blended Cement.

\section{Materials and Methods}

\subsection{Study Area}

The data were collected between January and September, 2013 in the five regions (Northern, Upper East, Upper West and the northern Brong Ahafo and Volta regions as shown in Figure 1 below) of Northern Ghana. This area also referred to as the northern savannah ecological zone in Ghana makes up about $48 \%$ of the country's total land area. Rainfall distribution is uni-modal giving a single growing season of 180 to 200 days with an annual mean of $1,100 \mathrm{~mm}$. The dry season starts in November and ends in March/April with maximum temperatures of about $42^{\circ} \mathrm{C}$ occurring towards the end of the dry season. The data collection was carried out in six districts across the zone, two districts in each of the three regions and one district each from northern Volta and Brong Ahafo.

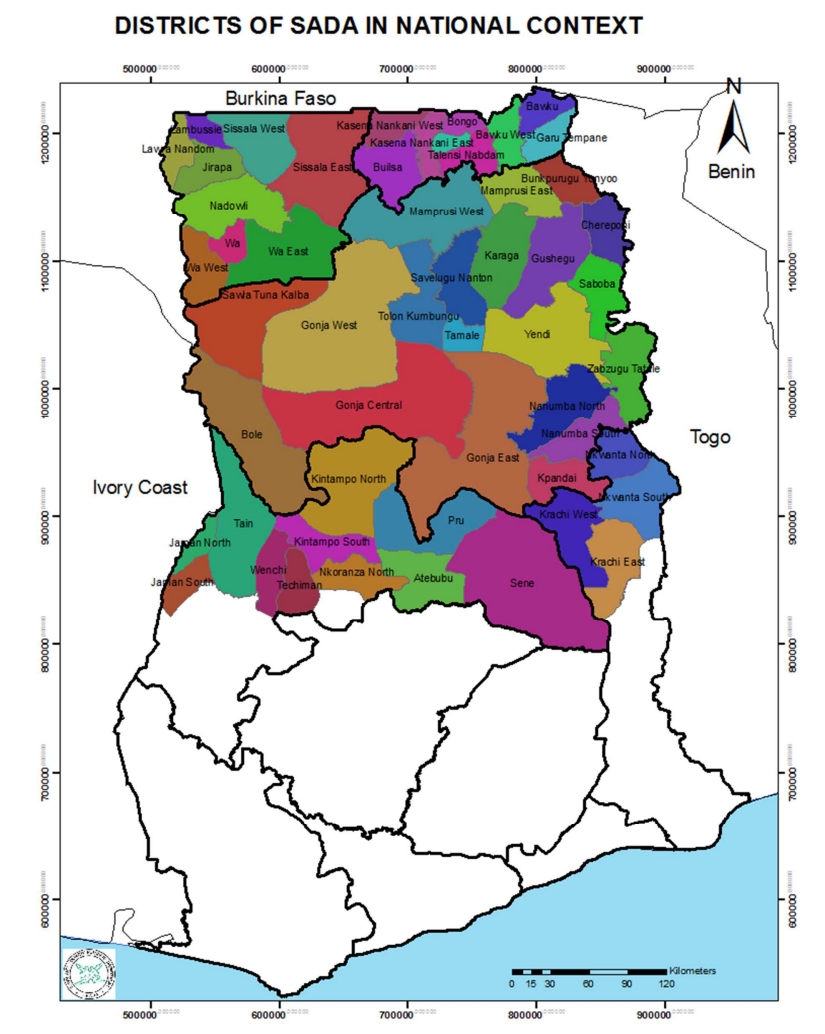

Source: SADA (Savannah Accelerated Development Authority)

Figure 1. A map of Ghana showing the study area.

\subsection{Materials}

\subsubsection{Sand}

The Sand used was clean, sharp river sand that was free from clay obtained from Dalung near Tamale in the Northern Region. The sand had a specific gravity of 2.60 .

\subsubsection{Cement}

The cement used was ordinary Portland cement from the Savannah cement company, located in Buipe in the Northern Region with properties conforming to BS 12(1971). The properties of the cement are shown in Table 1.

\subsubsection{Water}

The water used was potable, fresh, colourless, odourless and tasteless water that is free from organic matter of any type. 


\subsubsection{Corn Husk/Cob Ash (CCA)}

Corn husk and Cob used for this work was obtained from different farms located in the study area. The samples were allowed to dry under the sun for three days. The dried husk and cobs were burned slowly to ash in a gas kiln gradually for 3 days at $1100^{\circ} \mathrm{C}$ to obtain a finely divided ash, which is then sieved and kept ready for analysis (Rice Husk Ash, 2009). Chemical analysis of CCA was carried out in the laboratory of Chemistry Department at the Kwame Nkrumah University of Science and Technology. The properties are shown in Table 1.

\subsection{Manufacture of Sandcrete Blocks}

In this study, the solid blocks were manufactured with the use of the fabricating machine. One mix proportion of $1: 8$ was used in the production of $450 \mathrm{~mm} \times 225 \mathrm{~mm} \times 225 \mathrm{~mm}$ sandcrete block. One hundred and forty of $450 \mathrm{mmx} 150 \mathrm{~mm} \times 225 \mathrm{~mm}$ solid sandcrete blocks were produced. The quantities of materials obtained from the mix design were measured in each case by volume. The percentage of CCA content was varied in steps of $5 \%$ to a maximum of $40 \%$. For the experiment, hand mixing was employed, and the materials were turned over a number of times until an even colour and consistency was attained. Water was then added as required through a water hose, and the materials were further turned over to secure adhesion. It was then rammed into the machine mould, compacted and smoothened off with a steel face tool.

After removal from the machine moulds, the blocks were left on pallets under cover and cured by watering through a fine watering hose. Testing for crushing strength was then carried out at 7, 14, 21 and 28 days.

\section{Results and Discussion}

The results are presented in tabular and graphical forms. Table 2 shows the results of the compressive strength test at various percentages of CCA contents. Figure 1 shows the plot of compressive strength against percentage CCA content at ages 7, 14, 21 and 28 days. Figure 2: shows the relationship between CCA content and compressive strength.

\subsection{Effect of Corn Husk/Cob Ash on Compressive Strength}

The compressive strength values show that the inclusion of CCA in the cement matrix does not appreciably enhance the compressive strength of the sandcrete blocks. At 5\% replacement of CCA the compressive strength is $2.16 \mathrm{~N} / \mathrm{mm} 2$, which is $15 \%$ less than the control value. Figure 2 revealed that there is decrease in compressive strength as the proportion of coconut husk ash increases in the mix. The reduction in compressive strength for the replacement is due to low percentage of Calcium Oxide and Silicate Oxide in coconut husk ash. These two silicates are the main constituent of cement and are mainly responsible for the strength development. So as the cement content is gradually replaced by the coconut husk ash, the quantity of cement for hydration is reduced thereby the strength of the sandcrete blocks is reduced.

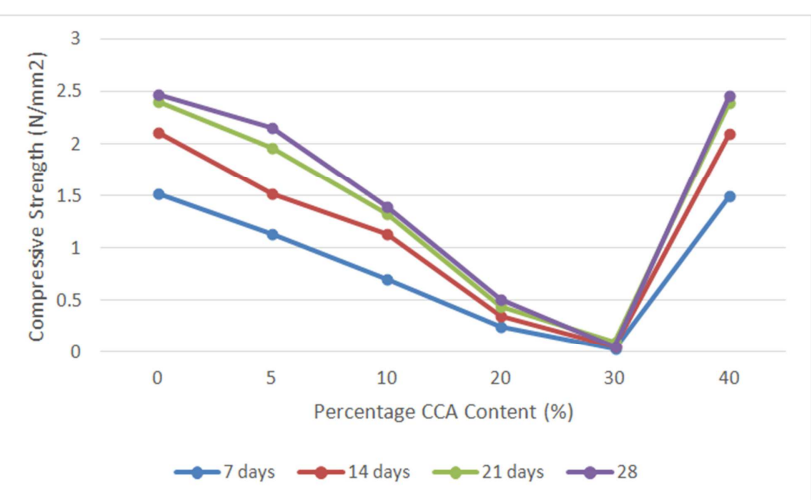

Figure 2. Diagram showing the relationship between CCA content and compressive strength.

The Nigeria National Building Code (16) recommended that average strength of 6 sandcrete block shall be $2.00 \mathrm{~N} / \mathrm{mm} 2$ and lowest strength for individual block shall be $1.75 \mathrm{~N} / \mathrm{mm} 2$ sandcrete block (18). For the $5 \%$ replacement of CCA in the cement matrix, the least value for the 28th day compressive strength is $2.03 \mathrm{~N} / \mathrm{mm} 2$, higher than recommendation by the code.

\subsection{Effect of CCA on Dry Density}

There is inconsistency in the dry density of the mix for the ages, but the maximum dry density for all the ages occurred at $15 \%$ CHA replacement. The maximum value of 1945.90 $\mathrm{Kg} / \mathrm{m} 3$ was recorded at 7 day test.

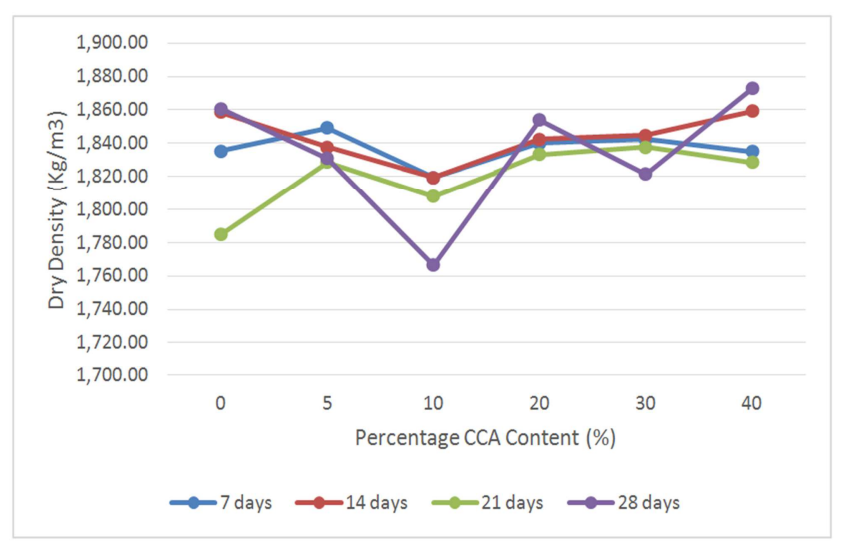

Figure 3. Diagram showing the relationship between dry density and CCA content.

\subsection{Weathering Conditions}

To determine the effect of weathering on the properties on the sandcrete blocks, the prepared samples that attained the desired compressive strength were exposed to the outdoor climatic conditions at various locations of the study area. The samples were exposed 28 days after manufacture in racks inclined $45^{\circ}$ to ensure maximum exposure during the rainy and dry seasons. 
The exposed specimens recorded stable or slight increases in compressive strength with no visible signs of deterioration.

\section{Conclusion}

The main conclusions derived from this investigation are as follows:

- Agriculture wastes such as corn cob/ husk ash shows good pozzolanic property in the production of sandcrete blocks.

- The maximum compressive strength of $2.16 \mathrm{~N} / \mathrm{mm} 2$ was obtained for the sandcrete block specimens at a percentage CCA content of $30 \%$.

- Corn husk/cob ash addition should not exceed 30\% of the weight of cement for best results.

- The maximum compressive strength achieved at 5\% is more than recommendation of $2.00 \mathrm{~N} / \mathrm{mm} 2$ recommended by National Building Code, for non load bearing walls.

\section{Recommendation}

1. Subsequent studies should be done on $0-40 \%$ replacement of cement with corn cob ash and in steps of $5 \%$.

2. Block/Concretes with the presence of ash content should be allowed to cure for 90days, by which pozzolanic activity of ash would have been concluded.

3. The use of locally available materials in infrastructure development will be met with the use of corn cob ash as a construction material and ultimately help meet our millennium development goals (MDG), thereby also enhancing the economic power of the rural dwellers if they are encouraged to plant maize from which these corn cobs could be gotten. The global green environment initiative will also be greatly influenced by the reduction in solid waste disposal.

4. The volume replacement attempted to get high strength concrete should be enhanced with super-plasticizers and a further reduction in the water-cement ratio so that concrete of very high strength can be achieved.

The following recommendations are drawn.

1. Use of other admixtures be incorporated with corn husk/cob ash in order to retard the hydration of water be studied

2. Other raw materials containing slightly higher calcium oxide and alumina could be used to improve the used of RHA as cement replacement.

1. Subsequent studies should be done on $0-40 \%$ replacement of cement with corn cob ash and in steps of $5 \%$.

2. Concretes with the presence of ash content should be allowed to cure for 90days, by which pozzolanic activity of ash would have been concluded.

3. The use of locally available materials in infrastructure development will be met with the use of corn cob ash as a construction material and ultimately help meet our millennium development goals (MDG), thereby also enhancing the economic power of the rural dwellers if they are encouraged to plant maize from which these corn cobs could be gotten. The global green environment initiative will also be greatly influenced by the reduction in solid waste disposal.

4. The volume replacement attempted to get high strength concrete should be enhanced with super-plasticizers and a further reduction in the water-cement ratio so that concrete of very high strength can be achieved.

\section{Acknowledgement}

The Authors wish to thank Mr. Abdul-Gafar Hamidu-Billa of the Department of Urban Roads Tamale and the Chemistry Department of the Kwame Nkrumah University of Science and Technology.

Table 1. Chemical Analysis result of Portland cement \& Corn Cob Ash.

\begin{tabular}{lll}
\hline Name of compounds & Cement (\%) & CCA (\%) \\
\hline Total Organic Content (Toc) & 1.7 & 0.25 \\
Calcium Oxide (CaO) & 62.32 & 0.005 \\
Silicate $\left(\mathrm{SiO}_{2}\right) 18.720 .005$ & 18.72 & 5.10 \\
Aluminate $\left(\mathrm{Al}_{2} \mathrm{O}_{3}\right)$ & 6.2 & 5.10 \\
Ferrite $\left(\mathrm{Fe}_{2} \mathrm{O}_{3}\right)$ & 0.94 & 2.48 \\
Magnesium $\mathrm{Oxide}(\mathrm{MgO})_{\text {Sulphur trioxide }\left(\mathrm{SO}_{3}\right)}^{1.62}$ & 0.09 \\
Sodium oxide $\left(\mathrm{Na}_{2} \mathrm{O}\right)$ & 1.1 & 0.12 \\
\hline
\end{tabular}

Table 2a-e. Compressive Strength Test Result of Sandcrete block Specimens Containing Various CCA.

\begin{tabular}{llll}
\hline $\begin{array}{l}\text { Percentage } \\
\text { CCA Content }\end{array}$ & $\begin{array}{l}\text { Age } \\
(\text { Days })\end{array}$ & $\begin{array}{l}\text { Dry Density } \\
\left(\mathbf{x} 1 \mathbf{3}^{\mathbf{3}} \mathbf{k g} / \mathbf{m}^{\mathbf{3}}\right)\end{array}$ & $\begin{array}{l}\text { Compressive Strength at } \\
\mathbf{2 8} \mathbf{d a y s}\left(\mathbf{N} / \mathbf{m m}^{\mathbf{2}}\right)\end{array}$ \\
\hline & 7 & 1.835 .30 & 1.52 \\
$0 \%$ & 14 & 1.858 .40 & 2.11 \\
$(\mathrm{CONTROL})$ & 21 & 1.784 .70 & 2.41 \\
& 28 & 1.860 .70 & 2.48 \\
\hline
\end{tabular}

\begin{tabular}{|c|c|c|c|}
\hline $\begin{array}{l}\text { Percentage } \\
\text { CCA Content }\end{array}$ & $\begin{array}{l}\text { Age } \\
\text { (Days) }\end{array}$ & $\begin{array}{l}\text { Dry Density } \\
\left(\times 10^{3} \mathrm{~kg} / \mathrm{m}^{3}\right)\end{array}$ & $\begin{array}{l}\text { Compressive Strength at } \\
28 \text { days }\left(\mathrm{N} / \mathrm{mm}^{2}\right)\end{array}$ \\
\hline \multirow{4}{*}{$10 \%$} & 7 & 1.819 .20 & 0.70 \\
\hline & 14 & 1.819 .20 & 1.14 \\
\hline & 21 & 1.807 .70 & 1.33 \\
\hline & 28 & 1.766 .30 & 1.40 \\
\hline $\begin{array}{l}\text { Percentage } \\
\text { CCA Content } \\
\end{array}$ & $\begin{array}{l}\text { Age } \\
\text { (Days) }\end{array}$ & $\begin{array}{l}\text { Dry Density } \\
\left(\times 10^{3} \mathrm{~kg} / \mathrm{m}^{3}\right)\end{array}$ & $\begin{array}{l}\text { Compressive Strength } \\
\text { at } 28 \text { days }\left(\mathrm{N} / \mathrm{mm}^{2}\right)\end{array}$ \\
\hline \multirow{4}{*}{$20 \%$} & 7 & 1.840 .00 & 0.25 \\
\hline & 14 & 1.842 .30 & 0.35 \\
\hline & 21 & 1.833 .00 & 0.44 \\
\hline & 28 & 1.853 .80 & 0.51 \\
\hline
\end{tabular}




\begin{tabular}{llll}
\hline $\begin{array}{l}\text { Percentage } \\
\text { CCA Content }\end{array}$ & $\begin{array}{l}\text { Age } \\
\text { (Days) }\end{array}$ & $\begin{array}{l}\text { Dry Density } \\
\left(\mathbf{x 1 0} \mathbf{k g}_{\mathbf{m}}^{\mathbf{3}}\right)\end{array}$ & $\begin{array}{l}\text { Compressive Strength } \\
\text { at 28 days }\left(\mathbf{N} / \mathbf{m m}^{2}\right)\end{array}$ \\
\hline & 7 & 1.842 .30 & 0.03 \\
$30 \%$ & 14 & 1.844 .60 & 0.06 \\
& 21 & 1.837 .70 & 0.11 \\
& 28 & 1.821 .50 & 0.06 \\
\hline & & & \\
\hline Percentage & Age & Dry Density & Compressive Strength at \\
CCA Content & (Days) & $\left.\mathbf{( x 1 0}^{\mathbf{3}} \mathbf{k g} / \mathbf{m}^{\mathbf{3}}\right)$ & $\mathbf{2 8}$ days $\left(\mathbf{N} / \mathbf{m m}^{2}\right)$ \\
\hline & 7 & 1.834 .80 & 1.50 \\
$40 \%$ & 14 & 1.859 .30 & 2.10 \\
& 21 & 1.828 .35 & 2.40 \\
& 28 & 1.872 .75 & 2.47 \\
\hline
\end{tabular}

\section{References}

[1] Bentur A. Fiber-reinforced cementitious materials. In: Skalny JP, editor. Materials science of concrete. Waterville: The American Ceramic Society; 1989. p. 223-84.

[2] Heinricks H, Berkenkamp R, Lempfer K, Ferchland H-J. Global review of technologies and markets for building materials. In: Moslemi AA, editor. Proceedings of the 7th International Inorganic- Bonded Wood and Fiber Composite Materials Conference. Moscow: University of Idaho; 2000. 12p. [Siempelkamp Handling Systems report].

[3] Harrison PTC, Levy LS, Pratrick G, Pigott GH, Smith LL. Comparative hazards of chrysotile asbestos and its substitutes: a European perspective. Environ Health Perspect 1999; 107(8): 60711.

[4] Giannasi F, Thebaud-Mony A. Occupational exposures to asbestos in Brazil. Int J Occupat Environ Health 1997; 3(2): $150-7$.

[5] Wood IM. Fibre crops: new opportunities for Australian agriculture. Brisbane: Department of Primary Industries Queensland; 1997. 102p.

[6] John VM, Zordan SE. Research and development methodology for recycling residues as building materials-a proposal. Waste Mgmt 2001; 21: 213-9.

[7] Swamy RN. Design for durability and strength through the use of fly ash and slag in concrete. In: Malhotra VM, editor. Proceedings of the 3rd CANMET/ACI International Conference on Advances in Concrete Technology. Auckland: ACI Publication SP-171-1; 1997. p. 1-72.

[8] Oliveira CTA, John VM, Agopyan V. Pore water composition of activated granulated blast furnace slag cements pastes. In: Proceedings of the 2nd International Conference on Alkaline

[9] Cements and Concretes. Kiev: Kiev State Technical University of Construction and Architecture; 1999. p. 18-20.

[10] Savastano Jr H, Warden PG, Coutts RSP. Brazilian waste fibres as reinforcement for cement based composites. Cem Concr Compos 2000; 22(5): 379-84.

[11] Zhu WH, Tobias BC, Coutts RSP, Langfors G. Air-cured banana-fibre-reinforced cement composites. Cem Concr Compos 1994; 16(1): 3-8.

[12] Higgins HG. Paper physics in Australia. Melbourne: CSIRO Division of Forestry and Forest Products; 1996.
[13] Coutts RSP, Ridikas V. Refined wood fibre-cement products. Appita 1982; 35(5): 395-400.

[14] Eusebio DA, Cabangon RJ, Warden PG, Coutts RSP. The manufacture of wood fibre reinforced cement composites from Eucalyptus pellita and Acacia mangium chemithermomechanical pulp. In: Proceedings of the 4th Pacific Rim Bio-Based Composites Symposium. Bogor: Bogor Agricultural University; 1998. p. 428-36.

[15] Coutts RSP, Kightly P. Bonding in wood fibre-cement composites. J Mater Sci 1984; 19:3355-9. Coutts RSP. Wood fibre reinforced cement composites. In: Swamy RN, editor. Natural fibre reinforced cement and concrete. Glasgow: Blackie; 1988. p. 1-62.

[16] Warden PG, Savastano Jr H, Coutts RSP. Fibre-cements fromBrazilian waste materials. In: Evans PD, editor. Proceedings of the $5^{\text {th }}$ Pacific Rim Bio-Based Composites Symposium. Canberra: ANU Forestry; 2000. p. 75-80.

[17] Wang S-D, Pu X-C, Scrivener KL, Pratt PL. Alkali-activated slag cement and concrete: a review of properties and problems. Adv Cem Res 1995; 7(27): 93-102.

[18] Bijen J. Blast furnace slag cement. DM_s-Hertogenbosch: Stichting Beton Prisma; 1996.

[19] Coutts RSP, Warden PG. Effect of compaction on the properties of air-cured wood fibre reinforced cement. Cem Concr Compos 1990; 12: 151-6.

[20] Coutts RSP. Highyield wood pulps as reinforcement for cement products. Appita 1986; 39(1): 31-5.

[21] Savastano H, Mabe I, Devito RA. Fiber cement based composites for civil construction. In: Proceedings of the 2nd International Symposium on Natural Polymers and Composites ISNaPol 98. S ao Carlos: Unesp/Embrapa/USP; 1998. p. 119-22.

[22] Taylor HFW. Cement chemistry. 2nd ed. London: Thomas Telford; 1997.

[23] Savastano Jr H, Agopyan V. Transition zone studies of vegetable fibre-cement paste composites. Cem Concr Compos 1999; 21(1): 49-57.

[24] Tol^edo RD, Filho K, Scrivener GL, England K. Durability of alkali-sensitive sisal and coconut fibres in cement mortar composites. Cem Concr Compos 2000; 22(2): 127-43.

[25] Olafusi Oladipupo S and Olutoge Festus A. "Strength Properties of Corn Cob Ash Concrete" Journal of Emerging Trends in Engineering and Applied Sciences (JETEAS) 3 (2): 297-301 Scholarlink Research Institute Journals, 2012 (ISSN: 2141-7016) jeteas.scholarlinkresearch.org.

[26] Bentur A, Akers SAS. The microstructure and ageing of cellulose fibre reinforced cement.

[27] Composites cured in a normal environment. Int $\mathrm{J}$ Cem Compos Lightweight Concr 1989; 11(2): 99-109.

[28] SARI, 1996. Savanna Agricultural Research Institute. Annual Report. 1996.

[29] FAO Statistical Databases. 2008. FAOSTAT: Agriculture Data. Available online: http://faostat.fao.org. 
[30] Morris, M. L., Tripp, R. and Dankyi, A. A. 1999. Adoption and Impacts of Improved Maize Production Technology. A Case Study of the Ghana Grains Development Project, Economics Program Paper 99-01. Mexico, D. F., CIMMYT. Available online http://www.cimmyt.org/Research/economics/map/research_re sults/program_papers/pdf/EPP\%2099_01.pdf.

[31] Neville, A. M. (1996). Properties of Concrete, $3^{\text {rd }}$ edition, Longman Scientific and Technical Publishing, London. Pp $58-70$.

[32] Saraswathy, V. and Ha-Won, S. (2007). Corrosion Performance of Rice Husk Ash Blended Concrete, Construction and Building Materials, Gale Group, Farmington Hills, Michigan. Retrieved on 12/10/2009 fromhttp://www.encyclopedia.com/doc/1G1-163421748.html.

[33] Sima, J. (1974). Portland-Pozzolona Cement: Need For a Better Application”. Indian Concrete J. 48: 33-34.

[34] Jackson, N. and Dhir, R. K. (1991). Civil Engineering Materials, 4th Edition, Macmillan ELBS, Hong Kong, Pp 144 -160 .
[35] Grith, D. H. (1974). Rice, 2nd Edition, Longman Limited, London. pp12-18. Adesanya D. A., [26] [34] [35] Raheem A. A. 2009. Development of Corn Cob Ash Blended Cement, Construction and Building Materials, (Vol. 23, pp. 347-352).

[36] Adesanya D. A., Raheem A. A. 2010. A study of the workability and compressive strength characteristics of corn cob ash blended cement concrete, Construction and Building Materials, (Vol. 23, pp. 311-317).

[37] Ogunfolami T. F. 1995. The Effect Of Thermal Conductivity and Chemical Attack on Corn Cob Ash Cement Concrete, Unpublished B. Sc. Project Report, Department of Building, Obafemi Awolowo University, Ile-Ife.

[38] Olutoge F. A., Bhashya V., Bharatkumar B. H., and Sundar Kumar S. 2010. Comparative Studies on Fly Ash and GGBS High Performance Concrete, Proceeding of National Conference on Recent Trend and Advance in Civil Engineering-TRACE 2010.

[39] Rice Husk Ash (2009). Rice Husk Ash. Retrieved on 8/10/2009 from http://www.ricehuskash.com/details.htm. 